\title{
Haemodynamic effects of haematocrit reduction in patients with polycythaemia secondary to cyanotic congenital heart disease
}

\author{
P J OLDERSHAW, M G ST JOHN SUTTON \\ From the Department of Cardiology, Brompton Hospital, Fulham Road, London
}

SUMMARY Acute reduction in haematocrit (without significant alteration of blood volume) in six patients with severe polycythaemia secondary to cyanotic congenital heart disease resulted in an increase in resting cardiac output without alteration in heart rate. Cardiac output was also increased during a constant-load exercise test after haematocrit reduction, and under these conditions total oxygen uptake was increased with consequent reduction in oxygen debt. These measurements confirm that the subjective improvement in such patients after haematocrit reduction is matched by physiological circulatory changes.

Patients with cyanotic congenital heart disease and secondary polycythaemia feel subjectively improved after venesection, the clinical manifestations of headache, lethargy, breathlessness, and anorexia being attributed to the increased haematocrit with attendant raised blood viscosity and intravascular red cell aggregation. ${ }^{1}$ The circulatory response to reduction in haematocrit has been assessed previously in such patients at rest, ${ }^{2}$ there being a reduction in peripheral vascular resistance and an increase in cardiac output, stroke volume, systemic blood flow, and systemic oxygen transport.

We have extended this work to investigate the effects of haematocrit reduction in patients with polycythaemia secondary to congenital heart disease, both at rest and during exercise.

\section{Methods}

Six patients with cyanotic congenital heart disease and secondary polycythaemia were studied. The initial haemoglobin level in each patient was greater than $20 \mathrm{~g} / \mathrm{dl}$. The underlying cardiac pathology was as follows. Case 1, a man of 39 years with an univentricular heart (and fixed rate pacemaker); case 2 , a man of 20 years with a ventricular septal defect and the Eisenmenger syndrome; case 3, a girl of 15 years with transposition of the great arteries with pulmonary stenosis and ventricular septal defect; case 4, a girl of 18 with tetralogy of Fallot; case 5, a 26-year-old man with tetralogy of Received for publication 10 April 1980
Fallot; and case 6, a 16-year-old boy with tetralogy of Fallot.

Each patient had haemoglobin, packed cell volume, and blood viscosity measurements made and was then subjected to an increasing work load on a bicycle ergometer (Siemens electrically stabilised load cycle ergometer). The equipment used during this test is shown in Fig. 1. The subject breathed through a mouth-piece with a unidirectional flow valve, and inspired ventilation was measured using a dry gas meter (Parkinson-Cowan). connected to a Mingograph recorder. The expired air passed through a valve box into a mixing chamber; air was sampled from this chamber continuously and passed over silica gel to remove water vapour. The dried mixed expired air passed to a mass spectrometer for oxygen and carbon dioxide measurement.

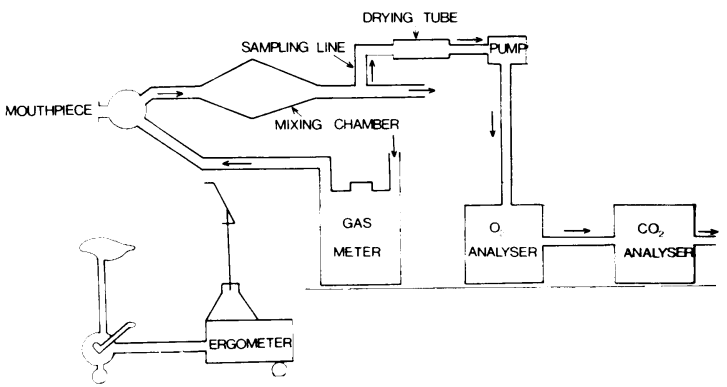

Fig. 1 Circuit diagram of the exercise equipment. 
The initial work load was $100 \mathrm{kpm} / \mathrm{min}$. If the patient was able to maintain exercise at this load for six minutes, he was allowed to rest and the test repeated at successive load increments of 100 $\mathrm{kpm} / \mathrm{min}$. In this way maximal work capacity could be assessed. This procedure was repeated three times to ensure that the maximal work capacity measured was not influenced in any way by a process of learning. As a safety precaution, exercise was stopped if the heart rate reached 85 per cent of the maximum predicted for age.

The patients were then exposed to a constant work load of six minutes duration, the power output selected being 50 per cent of the maximum work load previously ascertained. A steady resting state before starting this test was taken as the point where the ventilatory rate and mixed expired gas concentrations were constant. At this stage, a blood sample was taken for blood gas analysis from a vasodilated ear lobe. Blood gases were measured on this sample using a Corning 165 blood gas analyser. Ear lobe blood is virtually identical to arterialised blood. ${ }^{3}$ Baseline measurements of heart rate, ventilatory rate, $\mathrm{FeO}_{2}$ and $\mathrm{FeCO}_{2}$ (fractional concentrations of oxygen and carbon dioxide in expired air in $\mathrm{mmHg}$ respectively), were also made. Using these measurements $\mathrm{O}_{2}$ uptake/min at rest could be calculated using the equation:

$$
\begin{aligned}
\dot{\mathrm{V}} \mathrm{o}_{2}= & \dot{\mathrm{V}}_{\mathrm{i}} \times 0.2093-\frac{0.7903}{1.00-\left(\mathrm{FeCO}_{2}+\mathrm{FeO}_{2}\right)} \\
& \times \mathrm{FeO}_{2} \times \mathrm{STPD}
\end{aligned}
$$

where $\dot{\mathrm{Vo}}_{2}=$ volume uptake of oxygen per unit time $(1 / \mathrm{min})$

$\dot{\mathrm{V}}_{\mathbf{i}} \quad=$ inspired ventilation of air $(1 / \mathrm{min})$

STPD =standard temperature and pressure

$$
\text { dry }=\frac{273}{(273+T)} \times \frac{(\text { Pbar-SVP })}{760}
$$

Before the start of the constant work load test, resting cardiac output was also measured using the Fick principle. The Fick equation is given below:

$$
\text { Cardiac output }=\frac{\dot{\mathrm{V}} \mathrm{CO}_{2}}{\mathrm{C}_{\mathrm{v}} \mathrm{CO}_{2}-\mathrm{C}_{\mathrm{a}} \mathrm{CO}_{2}}
$$

where $\dot{\mathrm{V}} \mathrm{CO}_{2}=$ volume production of $\mathrm{Co}_{2}$ per unit time $(1 / \mathrm{min})$ and is given by

$$
\begin{aligned}
& \dot{\mathrm{V} C O}_{2}=\frac{\mathrm{FeCO}_{2} \times \dot{\mathrm{V}}_{\mathrm{i}} \times 0.7903}{1 \cdot 00-\left(\mathrm{FeCO}_{2}+\mathrm{FeO}_{2}\right)} \times \mathrm{STPD} \\
& \mathrm{C}_{\mathrm{vCO}}= \begin{array}{l}
\text { content (volume per } 100 \mathrm{ml}) \text { of } \\
\text { carbon dioxide in venous blood. }
\end{array} \\
& \mathrm{C}_{\mathrm{aCO}}= \text { content (volume per } 100 \mathrm{ml} \text { ) of } \\
& \text { carbon dioxide in arterial blood. }
\end{aligned}
$$

All these values with the exception of $\mathrm{C}_{\mathrm{y}} \mathrm{CO}_{2}$ were known and therefore to measure cardiac output

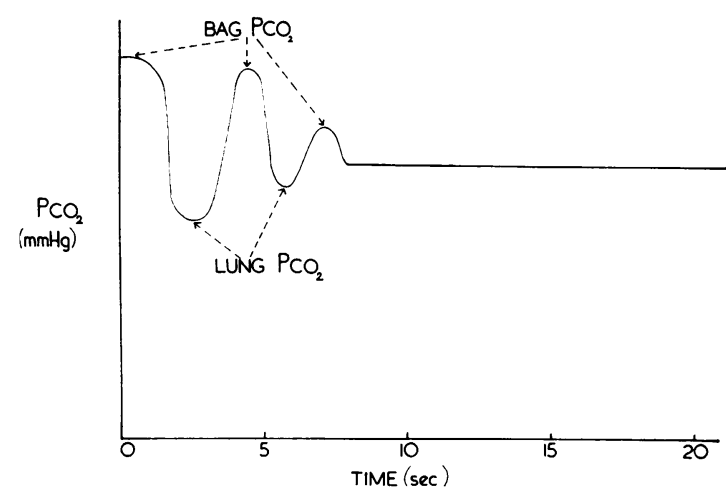

Fig. 2 Typical result from rebreathing experiment to measure content of $\mathrm{CO}_{2}$ in venous blood.

$\mathrm{C}_{\mathrm{v}} \mathrm{CO}_{2}$ had to be measured. This was done using a rebreathing technique with a 7 per cent carbon dioxide, 93 per cent oxygen mixture, the patient being connected to a bag containing this gas mixture via a pneumatic valve and then encouraged to breathe quickly and deeply in and out for four breaths to mix the gas in the bag with that in the lungs. After four breaths the patient was encouraged to breathe steadily for the remainder of a 20 second period, which produced an equilibrium pattern as shown in Fig. 2. An acceptable equilibrium should be produced between five and 10 seconds after the onset of the breathing procedure. During the plateau phase, lung, bag, and mixed venous blood are in equilibrium. The value for $\mathrm{P}_{\mathrm{v}} \mathrm{CO}_{2}$ obtained in this way is slightly higher than true mixed venous $\mathrm{PCO}_{2}$ in pulmonary capillary blood. The reasons for this are not fully understood, but an appropriate correction can be made using the following formula: $\mathrm{P}_{\mathrm{v}} \mathrm{CO}_{2} \quad$ (corrected) =equilibrium $\mathrm{PCO}_{2}-(0.23 \times$ equilibrium $\left.\mathrm{PCO}_{2}\right)-10$.

Using this value, resting cardiac output could be measured.

The true constant work load exercise test was then started. The patient was exercised at 50 per cent maximal working capacity for six minutes with continuous assessment of heart rate, inspired ventilatory rate, $\mathrm{FeO}_{2}$, and $\mathrm{FeCO}_{2}$. Values for heart rate, ventilation rate, and oxygen uptake during the sixth minute of exercise were then compared with the values for these at rest to assess the patient's response to exercise. A sample of ear lobe blood was also taken during the sixth minute for estimation of blood gases. Towards the end of the sixth minute, the patient was connected again to a bag containing 7 per cent carbon dioxide, 93 per cent oxygen, and $\mathrm{P}_{\mathrm{vCO}}$ estimated as before, thus allowing cardiac output during exercise to be measured.

By calculating oxygen uptake at each minute for 
six minutes, a plot of oxygen uptake against time could be produced (Fig. 3) during the constant work load. In all cases, equilibrium for oxygen uptake was established by the fourth minute. Thereafter, the value for oxygen uptake remained constant. The shaded area on this plot (Fig. 3) can therefore be taken as an estimate of oxygen debt, and was measured using planimetry.

Each patient was then venesected, three pints of blood being withdrawn, with three pints of plasma given as intravenous replacement. Three and 14 days later, the above procedures were repeated.

\section{Results}

All results given are mean \pm standard error of the mean. Differences between groups have been compared using Students' $t$ test.

Mean values for haemoglobin and packed cell volume fell significantly from $22.4 \pm 0.5 \mathrm{~g} / \mathrm{dl}$ and $66 \pm 1$ per cent before venesection to $18 \cdot 6 \pm 0 \cdot 4 \mathrm{~g} / \mathrm{dl}$ $(p<0.01)$ and $58 \pm 1$ per cent $(p<0.01)$ three days after venesection. This reduction was maintained on the 14th day after venesection: haemoglobin $18.8 \pm 0.5 \mathrm{~g} / \mathrm{dl}(\mathrm{p}<0.01)$, packed cell volume $58 \pm 1$ per cent $(\mathrm{p}<0.01)$. Table 1 shows the results for each individual. There was a corresponding fall in viscosity from $6.61 \pm 0.12$ before venesection to $5 \cdot 29 \pm 0.13$ three days after venesection and $5 \cdot 32 \pm 0 \cdot 1314$ days after venesection. In association with these changes in haemoglobin, packed cell volume, and viscosity, there was an increase in maximal exercise capacity from $333 \pm 30 \mathrm{kpm} / \mathrm{min}$ before venesection to $500 \pm 48 \mathrm{kpm} / \mathrm{min}$ three days afterwards $(p<0.01)$ and $483 \pm 43 \mathrm{kpm} / \mathrm{min} 14$ days afterwards $(p<0.01)$. There was also a signi-

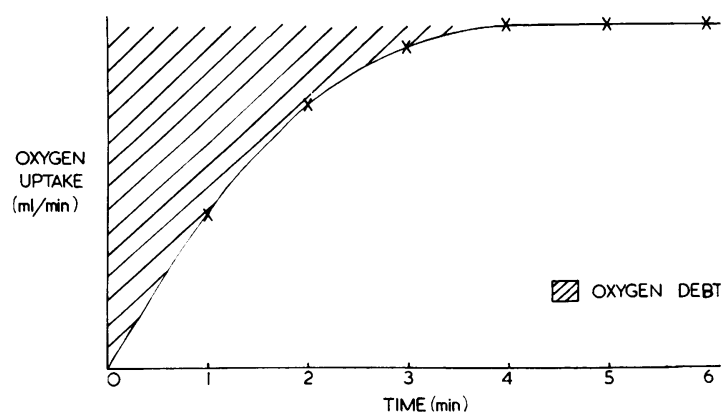

Fig. 3 Typical plot of $\mathrm{O}_{2}$ uptake against time during constant work load exercise test; hatched area represents the oxygen debt.

ficant increase in resting cardiac index from $2 \cdot 2 \pm 0.1$ before to $2 \cdot 9 \pm 0.2(p<0.01)$ at both three and 14 days after venesection, without significant change in heart rate. This implies an increase in mean stroke volume in these patients. There was no significant change in resting $\mathrm{PAO}_{2}$ and $\mathrm{PACO}_{2}$ after venesection. The mean values for oxygen uptake rose $(325,358$, and $375 \mathrm{ml} / \mathrm{min})$ and the mean values for ventilatory rate fell $(12.9,12.7$, and $12 \cdot 1$ $1 / \mathrm{min}$ ), both sets of figures respectively before venesection and three and 14 days after venesection, but these were not significant changes. During the sixth minute of a steady-state exercise test, there was a significant increase in cardiac index at both three and 14 days after venesection as compared with measurements before venesection (Table 2). If the results are related to the values before venesection with this as unity, then the mean cardiac index was 1.14 at three days, and 1.18 at 14 days after venesection. There was a similar increase in normalised

Table 1 Patients at rest

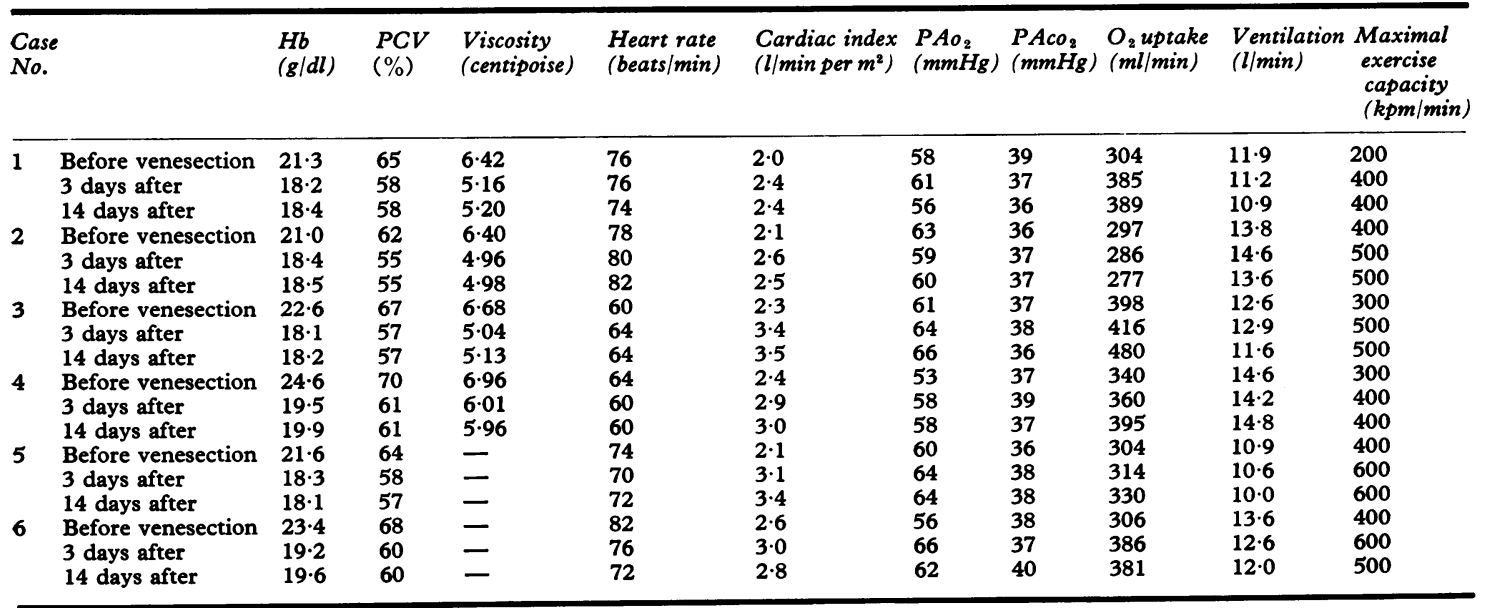


Table 2 Patients in 6th minute of steady state exercise test ( $\frac{1}{2}$ max work load before venesection)

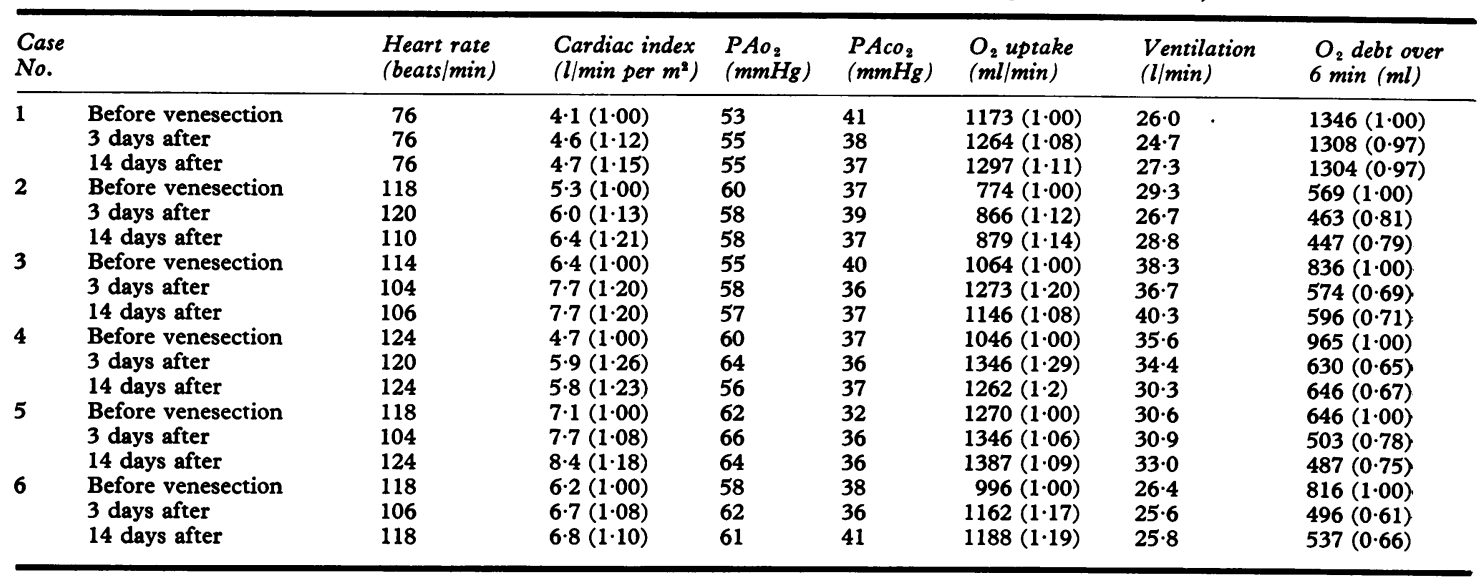

Values in brackets are normalised for comparison in relation to measurements before venesection.

$\mathrm{O}_{2}$ uptake from 1.0 to 1.15 and 1.14 at three and 14 days. Normalised $\mathrm{O}_{2}$ debt, however, fell from 1.0 to 0.75 and 0.76 , respectively. There was no difference in the response of heart rate, $\mathrm{PAO}_{2}, \mathrm{PCCO}_{2}$ or ventilatory rate to exercise between measurements before and after venesection.

\section{Discussion}

The development of secondary polycythaemia with cyanotic congenital heart disease is a compensatory phenomenon in response to the low arterial oxygen tension. The polycythaemia, unlike that of polycythaemia rubra vera, is characterised by increased haematocrit (and therefore red cell volume) with normal circulatory whole blood volume. ${ }^{4}$ Theoretically, the increased red cell volume should provide an increased oxygen-carrying capacity ${ }^{5}{ }^{6}$; this effect, however, is offset by the increase in viscosity which affects blood flow and therefore tissue perfusion. ${ }^{1}$ One direct effect of increased viscosity is a reduction in cardiac output ${ }^{7}{ }^{8}$; a second is increased plasma skimming. (When blood is flowing along a vessel, there is a tendency for cells to concentrate in the core of the lumen creating a "relatively cell-free layer" of plasma close to the vessel wall. Capillaries branching off from such vessels are therefore supplied with blood containing a greater percentage of plasma than red blood cells than elsewhere; this effect is called plasma skimming.) As a result of increased plasma skimming, perfusion of peripheral tissues (and therefore oxygen transfer) will be impaired. Similarly in the lungs, oxygen uptake will be reduced because of increased ventilationperfusion mismatch. It is obvious therefore that the development of polycythaemia confers some ad- vantages on the individual but also some disadvantages. The physiological effects on the circulation of venesection with fluid replacement have not as yet been fully investigated; we carried out such studies in patients both at rest and during exercise.

At rest, in association with the fall in haematocrit, there was an increase in cardiac index without change in heart rate, implying an increased stroke volume. Similar results were found by Rosenthal et $a .^{2}$ and were thought to be the result of a fall in peripheral vascular resistance consequent on reduced viscosity. These workers also noted a substantial improvement in systemic oxygen transport, defined as the amount of oxygen supplied but not extracted by the tissues per minute per unit weight of body. They attributed this increase in oxygen transport primarily to increase in systemic blood flow since oxygen-carrying capacity is always reduced and arterial oxygen saturation often declines as a result of haematocrit reduction. They postulated that the advantage of an increase in oxygen transport after isovolaemic red cell volume reduction was in the provision of a greater oxygen reserve available for tissue utilisation on exercise. Murray et $a l .{ }^{9}$ showed that maximum systemic oxygen transport usually occurred at normal haematocrit values. In our study, mean oxygen uptake at rest increased after venesection, but the results failed to reach statistical significance.

During exercise, a significant increase $(p<0.01)$ in cardiac index was again noted at both three and 14 days after venesection when compared with values before venesection. In addition, during exercise there was a significant increase $(p<0.05)$ in oxygen uptake; consequently $\mathrm{O}_{2}$ debt was reduced 
$(p<0.05)$. The increase in oxygen uptake could be explained on the basis of improved circulation to peripheral tissues (reduced vascular resistance, reduced plasma skimming) and improved circulation to the capillary bed of the lung (reduced ventilation-perfusion mismatch) as described above. If the transfer of oxygen from the lungs to the blood, and the blood to the tissues is improved, oxygen debt during exercise would theoretically be reduced.

This study, then, confirms that the subjective improvement in patients with cyanotic congential heart disease and secondary polycythaemia is matched by objective changes, there being an increase in both cardiac output and oxygen uptake by peripheral tissues.

\section{References}

1 Replogle RL, Meiselman HJ, Merrill EW. Clinical implications of blood rheology studies. Circulation 1967; 36: 148-60.

2 Rosenthal A, Nathan DG, Marty AT, et al. Acute hemodynamic effects of red cell volume reduction in polycythemia of cyanotic congenital heart disease. Circulation 1970; 42: 297-307.
3 Godfrey S, Wozniak ER, Courtenay-Evans RJ, Samuels CS. Ear lobe blood samples for blood gas analysis at rest and during exercise. $\mathrm{Br} \mathcal{F}$ Dis Chest 1971 ; 65: 58-64.

4 Vérel D. Blood volume changes in cyanotic congenital heart disease and polycythemia rubra vera. Circulation 1961; 23: 749-53.

5 Murray JF, Gold P, Johnson BL Jr. The circulatory effects of haematocrit variations in normovolemic and hypervolemic dogs. F Clin Invest 1963; 42: $1150-9$.

6 Richardson TQ, Guyton AC. Effects of polycythemia and anemia on cardiac output and other circulatory factors. Am f Physiol 1959; 197: 1167-70.

7 Dill DB. Life, heat and altitude. London and Oxford: Harvard University Press, 1938: 132-5.

8 Pugh LGCE. Cardiac output in muscular exercise at 5,800 m (19,000 ft). F Appl Physiol 1964; 19: 441-7.

9 Murray JF, Gold P, Johnson BL Jr. Systemic oxygen transport in induced normovolemic anemia and polycythemia. Am f Physiol 1962; 203: 720-4.

Requests for reprints to Dr P J Oldershaw, Cardiac Department, Brompton Hospital, Fulham Road, London SW3 6HP. 